Article

\title{
Diversity and Adaptation of Currently Grown Wheat Landraces and Modern Germplasm in Afghanistan, Iran, and Turkey
}

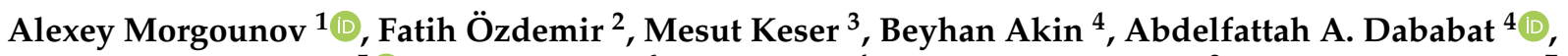 \\ Susanne Dreisigacker ${ }^{5}{ }^{\circledR}$, Saber Golkari ${ }^{6}$, Emrah Koc ${ }^{4}$, Murat Küçükçongar ${ }^{2}$, Hafiz Muminjanov ${ }^{7}$, Ajit Nehe ${ }^{4}{ }^{\oplus}$, \\ Awais Rasheed ${ }^{8}\left(\mathbb{D}\right.$, Mozaffar Roostaei ${ }^{9}{ }^{(1)}$, Deepmala Sehgal ${ }^{5}$ and Rajiv Sharma ${ }^{10, *(1)}$
}

check for updates

Citation: Morgounov, A.; Özdemir, F.; Keser, M.; Akin, B.; Dababat, A.A.; Dreisigacker, S.; Golkari, S.; Koc, E.; Küçükçongar, M.; Muminjanov, H.; et al. Diversity and Adaptation of Currently Grown Wheat Landraces and Modern Germplasm in Afghanistan, Iran, and Turkey. Crops 2021, 1, 54-67. https://doi.org/ $10.3390 /$ crops 1020007

Academic Editor: Kenneth J. Moore

Received: 25 May 2021

Accepted: 16 June 2021

Published: 1 July 2021

Publisher's Note: MDPI stays neutral with regard to jurisdictional claims in published maps and institutional affiliations.

Copyright: (C) 2021 by the authors. Licensee MDPI, Basel, Switzerland. This article is an open access article distributed under the terms and conditions of the Creative Commons Attribution (CC BY) license (https:/ / creativecommons.org/licenses/by/ $4.0 /)$.
1 Food and Agriculture Organization of the United Nations, Riyadh 11421, Saudi Arabia; Alexey.morgounov@gmail.com

2 Bahri Dagdas International Agricultural Research Institute, Konya 42020, Turkey; fatihozde@hotmail.com (F.Ö.); kucukcongar@gmail.com (M.K.)

3 International Center for Agricultural Research in Dry Areas (ICARDA), Ankara 06170, Turkey; m.keser@cgiar.org

4 International Maize and Wheat Improvement Center (CIMMYT), Ankara 06810, Turkey; b.akin@cgiar.org (B.A.); a.dababat@cgiar.org (A.A.D.); e.koc@cgiar.org (E.K.); ajit.nehe@gmail.com (A.N.)

5 International Maize and Wheat Improvement Center (CIMMYT), Texcoco CP56237, Mexico; s.dreisigacker@cgiar.org (S.D.); d.sehgal@cgiar.org (D.S.)

6 Agricultural Biotechnology Research Institute, Karaj 31585, Iran; S.golkari@abrii.ac.ir

7 Food and Agriculture Organization of the United Nations, 00153 Rome, Italy; hafiz.muminjanov@fao.org

8 Department of Plant Sciences, Quaid-i-Azam University, Islamabad 45320, Pakistan; arasheed@qau.edu.pk

9 Dryland Agricultural Research Institute, Agricultural Research Education \& Extension Organization, Maragheh 56136, Iran; roustaii@yahoo.com

10 International Maize and Wheat Improvement Center (CIMMYT), Kabul 1011, Afghanistan

* Correspondence: rk.sharma@cgiar.org

Abstract: Collection of wheat landraces (WLR) was conducted in Afghanistan, Iran, and Turkey in 2010-2014. A representative subset of this collection was used in the current study and included 45 bread wheat landraces from Turkey, 19 from Iran, and 20 from Afghanistan. This material was supplemented by 73 modern cultivars and breeding lines adapted to semiarid conditions and irrigated conditions. Overall, 157 genotypes were tested in Turkey in 2018 and 2019 and in Afghanistan and Iran in 2019 under rainfed conditions to compare performance of WLR and modern material. The germplasm was genotyped using a high density Illumina Infinium $25 \mathrm{~K}$ wheat SNP array and KASP markers for agronomic traits. The average grain yield ranged between 2.2 and $4.0 \mathrm{t} / \mathrm{ha}$ depending on the site and year. Three groups of landraces demonstrated similar average grain yield, though Afghanistan material was slightly higher yielding not only in Afghanistan but also in Turkey. Modern material outyielded the landraces in two environments out of four. The highest yielding landraces were competitive with the best modern germplasm. Frequency of gene Sus2-2B affecting 1000 kernel weight was $64 \%$ in WLR and only 3\% in modern material. Presence of positive allele of Sus $2-2 B$ increased 1000 kernel weight by nearly $4 \%$. Breeding strategy to improved landraces and modern cultivars is discussed.

Keywords: wheat; diversity; landraces; cultivars; yield components; molecular markers

\section{Introduction}

Wheat is an important crop in Central and West Asia, covering an estimated 20 Mha in diverse agroecological environments [1]. The crop is grown both under irrigation and semiarid rainfed conditions with grain yield varying from 2 to $6 \mathrm{t} / \mathrm{ha}$. The region is also characterized by exceptionally high consumption of bread and other wheat products. The share of daily calories originating from wheat products reaches $40-50 \%$ in countries such as Afghanistan, Tajikistan, and Uzbekistan (FAOSTAT). Three major wheat producing 
countries in the region in 2019 were Iran (8.0 Mha), Turkey (6.8 Mha), and Afghanistan (2.3 Mha) (FAOSTAT). There are two distinct wheat production environments. Lowlands and valleys below 500-700 masl normally grow spring wheat, which is planted in November and harvested in May-June. High altitude regions above 700-1000 masl are cultivated by either irrigated or rainfed winter wheat from October till July. Typical winter wheat regions are the Anatolian Plateau of Turkey, northwestern provinces of Iran, and eastern part of Afghanistan.

Both spring and winter wheat production went through a Green Revolution in the 1970s, replacing old cultivars with modern semidwarf high-yielding lines. In the case of spring wheat, the introduction and utilization of the CIMMYT-derived germplasm was the main factor contributing to yield increase. Conversion of winter wheat to modern cultivars was based on the introduction and use of Russian and European germplasms possessing diverse dwarfing genes and 1B.1R translocation. There are documented genetic gains in grain yield and other traits for both spring and winter wheat in the region over the past 30-40 years [2,3]. The genetic progress has been realized in production gains for spring wheat but to a lesser extent for winter wheat. The latter is characterized by much more diverse production environments due to altitude, soil, growing techniques, and climate variation. Some areas represent production challenges due to poor soils, dry and hot climate, severe cold, and short growing season at high altitudes. Winter wheat production in the region is also more fragmented with smaller fields, and it is frequently subsistence based. For this reason, wheat landraces are still grown in some countries of the region: Afghanistan [4], Iran [5], Tajikistan [6], Turkey [7], and Uzbekistan [8].

An unprecedented increase in interest in wheat landraces has occurred over the last decade. This is partly driven by the potential benefits of ancient wheats or landraces compared with modern wheat cultivars [9]. Further studies including a wider range of genotypes of ancient and modern wheat species are needed to demonstrate these benefits. In addition, consumers have developed a growing interest in products made from "heirloom cultivars". Dwivedi et al. [10] defined these as cultivars that have been grown for a long time ( $>50$ years) and have a heritage that has been preserved by regional, ethnic, or family groups. The other important factor contributing to the focus on wheat landraces is their superior adaptation to abiotic stresses and diversity. The landraces are grown on a small scale by dedicated farmers (including organic farmers) in Europe and North America but also by small-scale farmers in Central and West Asia who depend on them for their daily bread.

Starting from 2009, an inventory of wheat landraces was competed in Turkey, Tajikistan, and Uzbekistan by the International Winter Wheat Improvement Program (IWWIP, Turkey-CIMMYT-ICARDA), FAO, and the national partners. More than 2000 wheat landraces samples were collected in Turkey from 1500 farmers in 61 provinces [7]. They were described, characterized, and evaluated using phenotypic and genomic tools and deposited in the Turkish Seed Gene Bank in Ankara. Field evaluation of the landraces identified superior genotypes that have been used in breeding drought tolerant germplasm. In Tajikistan, more than 60 distinct wheat landraces were collected in five mountainous regions up to 2500 masl [6]. They were thoroughly phenotyped and genotyped, conserved in the gene bank, and used in breeding. In Uzbekistan, the inventory resulted in more than 30 diverse bread wheat landraces collected in three regions in the western Tian Shan mountains [8]. Agronomically superior landraces were multiplied and returned to the farming communities. Similarly, though undocumented, collections were conducted in Afghanistan and Iran. These two countries are characterized by relatively large areas planted by wheat landraces: at least 1 Mha in Afghanistan and 1 Mha in Iran. On a regional level it was obvious that tremendously diverse wheat landraces have been maintained by the farming communities primarily due to their excellent quality for local products, specific adaptation to harsh environments, and straw yield and quality. There was a need for coordinated efforts for on-farm conservation of wheat landraces in the region. 
In 2016, the International Maize and Wheat Improvement Center (CIMMYT) was awarded a regional project on wheat landraces by the Benefit-Sharing Fund of the International Treaty on Plant Genetic Resources for Food and Agriculture. The main objective was to evaluate the collected material, identify diverse superior landraces, multiply them, and return them back to farming communities assuring their continuous cultivation as well as use in breeding. The project focused on four provinces in Turkey (Konya, Malatya, Mardin and Tokat), two provinces in Iran (East Azerbaijan and North Khorasan), and two provinces in Afghanistan (Balkh and Herat). The landraces collected from these provinces were multiplied and exchanged between three countries to share with the gene banks and establish a common trial for their field evaluation, use in the breeding programs, and transfer to the farming communities. Overall, 84 wheat landraces were exchanged, and they were supplemented by 73 genotypes representing modern cultivars and breeding lines developed by IWWIP and other breeding programs. This trial comprising wheat landraces (WLR) and modern germplasm (MG) was evaluated in 2018 and 2019 in Turkey and in 2019 in Afghanistan and Iran. The objective of the study was comparative assessment of adaptation, agronomic performance, and diversity of WLR and MG to develop a breeding strategy and on-farm conservation approaches.

\section{Materials and Methods}

\subsection{Material Used in the Study}

The list of material used in the study is presented in Table S1. The trial comprised two groups of material: bread WLR (84 entries) recently collected from four provinces of Turkey and two each of Iran and Afghanistan (Figure 1) and MG (73 entries including four checks). Many WLR collected from the farmers represented mixtures of morphotypes. They went through consecutive spike selection, head-rows testing, and unreplicated yield trials as described by Morgounov et al. [7] prior to inclusion in this study. The main objective of this purification process was to maintain the WLR diversity and select agronomically superior material. This process took place at respective research institutes in the three countries. Strictly speaking the study included lines originating from wheat landraces collected from farmers' fields. They included 45 entries from Turkey, 20 from Afghanistan, and 19 from Iran. In the case of Turkey and Afghanistan, this represents a small part of all WLR diversity collected and present in farm fields. In northwestern Iran, the old cultivar Sardari, originating from a landrace, dominates the production with only a few other landraces found in farmers' fields. The material from Iran included 14 Sardari biotypes collected from across the region.

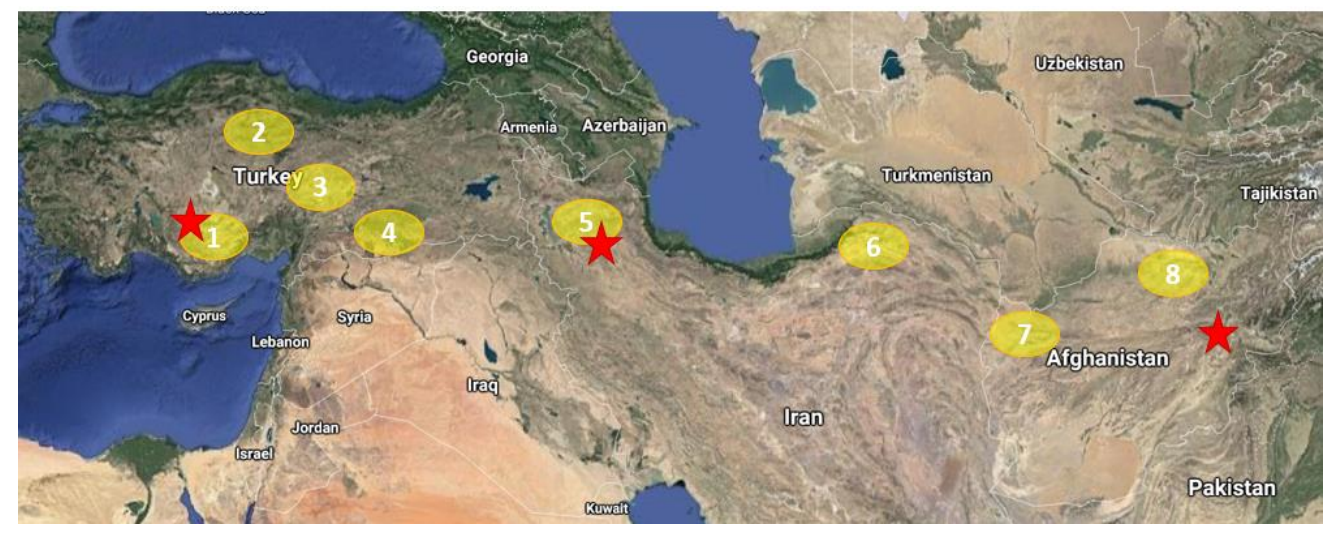

Figure 1. Countries and provinces from which WLR were collected (Turkey: 1-Konya, 2-Tokat, 3-Malatya, 4-Mardin; Iran: 5-East Azerbaijan, 6-North Khorasan; Afghanistan: 7-Herat; 8-Balkh) and the sites where field trails were conducted (Konya, Turkey; Maragheh, Iran, Kabul, Afghanistan).

MG included in the study represented two types of adaptation: material destined for high-yielding irrigated environments (39 entries) and germplasm developed for semiarid 
moisture-stressed regions (34 entries). Both groups of material included Turkish cultivars as local checks: cultivars Bezostaya-1, Kate a-1, Konya 2002, and Nacibey for irrigated types and Gerek, Karahan-99, Mufitbey, and Sonmez for semiarid types. IWWIP-derived breeding lines constituted the bulk of material: 19 entries in an irrigated group and 12 in a semiarid group. The remaining germplasm represented cultivars and breeding lines from CIMMYT-Mexico, Eastern Europe, and Kansas, USA. All the MG went through several years of field evaluation and selection under respective irrigated or moisture-stressed conditions and demonstrated their competitiveness against the local checks. The trial conducted in Iran did not include irrigated MG.

\subsection{Field Trials and Phenotyping}

The trial was phenotyped for common agronomic traits on $6 \mathrm{~m}^{2}$ plots under rainfed conditions at the Bahri Dagdas International Agricultural Research Institute in Konya (BDIARI), Turkey (Figure 1) during the 2018 and 2019 growing seasons. The material was also phenotyped at the Dryland Agricultural Research Institute in Maragheh, Iran and the Afghanistan Research Institute of Agriculture in Kabul in 2019. An alpha-lattice experimental design was used with two replicates. At the three stations, the trials were planted after black (clean) fallow and followed commonly applied agronomic practices for wheat: planting in October, nitrogen fertilizer application in spring after snow melt (N30-50), weed control using herbicides, and harvest in July.

The morphological descriptions of all material were based on spike morphological traits: glume color and pubescence, presence and color of awns, and grain color. The combination of these highly inherited traits defines the botanical variety (or morphotypes) as described by Zuev et al. [11] and as presented in Table S2. Agronomic traits and yield components were evaluated following the methodology described in Pask et al. [12]. In addition, the material was evaluated for stripe rust resistance at the Haymana Station of Central Field Crop Research Institute, Turkey and for leaf rust resistance at the Maize Research Station, Sakarya, Turkey in 2018 and 2019. Artificial inoculation with the mixture of local pathotypes was used at both sites and led to high disease severity. Growth habit was evaluated by planting the material in late April when the minimum daily temperatures exceeded $10^{\circ} \mathrm{C}$. The genotypes coming to heading were classified as spring types whereas the entries remaining at the tillering stage were classified as winter types. Facultative types were also identified as heading substantially later than did spring types. In 2019, digital photos were taken at BDIARI of each plot starting from early March (tillering) till early June (milk stage) every 10-15 days. The RGB digital image-based vegetation index, green area per meter square, was calculated using equations from BreedPix open-source software [13]. Statistical analysis of the field data was limited to ANOVA of agronomic traits from replicated trials and standard error calculation using Excel software.

Weather conditions in Konya in 2018 were characterized by lack of moisture prior to heading resulting in drought and yield reduction to around $2 \mathrm{t} / \mathrm{ha}$. In 2019, the precipitation was sufficient; the plants grew tall, and some entries lodged during maturity. The grain yield exceeded $4 \mathrm{t} /$ ha without irrigation mainly due to higher precipitation. Weather conditions were moderately favorable in Afghanistan and Iran in 2019, resulting in grain yield averaging $3 \mathrm{t} / \mathrm{ha}$. Winter conditions were mild in Turkey and Afghanistan without visible frost or cold damage. However, cold damage was observed in Iran. Among the diseases, stripe rust was observed in Kabul in 2019 but did not affect grain yield.

\subsection{DNA Diversity and Molecular Markers}

All the materials were genotyped using a high density Illumina Infinium $25 \mathrm{~K}$ wheat SNP (Single-nucleotide polymorphism) array (TraitGenetics GmbH, Gatersleben, Germany). A filtered set of 15,208 SNPs having missing data $<20 \%$ and minor allele frequency $\geq 5 \%$ were included in the analyses. To estimate the number of subgroups, principal components analysis (PCA) was performed in R package "stats" and a 3D view of the PCA was drawn using the R package "rgl". Polymorphic information content (PIC) [14] was 
used to estimate total diversity and compare different subpopulations observed in the PCA analysis using a custom R script.

Allele-specific KASP markers for 98 different loci were additionally deployed (Table S3) with analysis performed by Biosearch Technologies (Teddington, Middlesex, UK). The primer sequences, amplification conditions, and detailed genotyping procedures of each gene are described in $[15,16]$. KASP markers for which one of the alleles was represented at relatively higher frequency $(>70 \%)$ than that of the other alleles were not considered for evaluation of marker-trait association. For a number of markers, the related phenotypic data to evaluate alleles effects on the traits were not available. The marker-trait associations were identified by comparing the average values with the respective standard errors.

\section{Results}

\subsection{Morphological and Genetic Diversity}

The visual appearance of wheat largely depends on the spike glume color and awns, which provide distinction of specific genotypes after anthesis and especially at maturity. Distribution of the studied material across botanical varieties is presented in Table S4. In total, 21 botanical varieties were identified among the WLR and MG, including seven in Afghan WLR, five in Iranian WLR, and 14 in Turkish WLR. There were rare club and intermediate club-bread wheat landraces. MG was assigned to only six botanical varieties with two (erythrospermum and greacum) comprising over $80 \%$. Botanical diversity of WLR from all three countries comprised 19 morphotypes. There were substantial differences in the spike glume and grain colors: $51 \%$ of WLR had red spike color versus only $9 \%$ of MG; $73 \%$ of WLR had white grain versus only 33\% of MG. There was an obvious change from WLR with a red spike and white grain to MG primarily with a white spike and red grain.

Grouping of the material based on SNP diversity is presented in Figure 2. As expected, modern cultivars and breeding lines clustered together independently of the whether they were bred for irrigated or drought conditions. Three Afghan WLR also clustered with MG, suggesting that they might derive from cultivated cultivars and were misclassified as landraces. Afghan and Turkish WLR formed two distinct groups whereas Iranian WLR overlapped these two groups. This indicates isolation of Afghan and Turkish landraces and interchange of Iranian WLR with neighboring countries through seed exchange. PIC estimated for all germplasm was 0.31 based on all 15,208 SNPs, whereas it was 0.30 and 0.27 for MG and WLR, respectively. These results revealed slightly higher diversity of MG as compared to that of WLR and suggest that sufficiently high diversity is maintained in breeding lines and cultivars. Presence of Turkish, East European, and USA germplasm in MG also contributed to its higher diversity.

\subsection{Adaptation Traits}

Growth habit is important for adaptation to the growing environment. The majority of the WLR from Iran and Turkey and MG demonstrated a winter growth habit adapted for autumn planting and cold winter (Table 1). All WLR from Afghanistan were spring habit. They originated from Herat Province, lying at 800-1000 masl, and Balkh Province, situated at 300-600 masl. Spring wheat landraces grown in these provinces possess sufficient cold tolerance to survive winter. Consequently, the farmers have flexibility of planting them in early spring if fall planting fails. Turkish WLR were 5 days later compared to all other material (Table 1 and Table S5). This character may be important to take advantage of late rains in the mountains, which contribute to grain filling. As expected, WLR were on average $10 \mathrm{~cm}$ taller than $\mathrm{MG}$ or even $20 \mathrm{~cm}$ taller compared to material bred for irrigated conditions. 


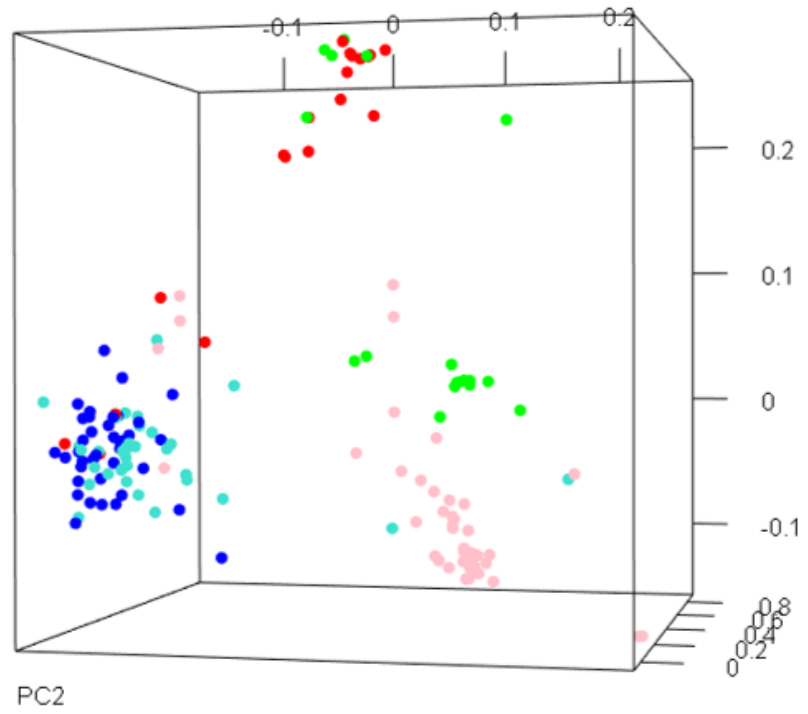

PC1

Modern varieties: Irrigated Landraces from Afghanistan

Modern varieties: Semiarid Landraces from Iran

Landraces from Turkey

Figure 2. Grouping of WLR and MG based on SNP diversity.

Table 1. Agronomic parameters of wheat landraces and modern germplasm tested in Afghanistan, Iran, and Turkey, 2018-2019.

\begin{tabular}{|c|c|c|c|c|c|c|c|c|}
\hline \multirow{2}{*}{ Trait } & \multirow{2}{*}{$\begin{array}{l}\text { Number of } \\
\text { Sites } \times \text { Years }\end{array}$} & \multicolumn{3}{|c|}{ Wheat Landraces } & \multicolumn{2}{|c|}{ Modern Germplasm } & \multicolumn{2}{|c|}{ All } \\
\hline & & AFG & IRN & TUR & IRR & SA & WLR & MG \\
\hline Number of genotypes & & 20 & 19 & 45 & 39 & 34 & 84 & 73 \\
\hline $\begin{array}{l}\% \text { of genotypes } \\
\text { with winter growth } \\
\text { habit }\end{array}$ & 1 & 0 & 79 & 62 & 80 & 70 & 51 & 76 \\
\hline $\begin{array}{l}\text { Days to heading } \\
\text { from Jan. } 1\end{array}$ & 3 & $129 \pm 0.6$ & $129 \pm 0.4$ & $135 \pm 0.5$ & $130 \pm 0.4$ & $130 \pm 0.4$ & $132 \pm 0.4$ & $130 \pm 0.3$ \\
\hline Plant height, $\mathrm{cm}$ & 3 & $98 \pm 2.2$ & $91 \pm 1.3$ & $90 \pm 0.9$ & $78 \pm 1.3$ & $86 \pm 1.9$ & $92 \pm 0.9$ & $82 \pm 1.2$ \\
\hline Stripe rust, \% & 2 & 33.2 & 36.6 & 30.1 & 10.2 & 8.3 & 28.7 & 10.1 \\
\hline Leaf rust, $\%$ & 2 & 57.0 & 61.9 & 54.2 & 26.7 & 26.3 & 56.6 & 29.2 \\
\hline Lodging, $\%$ & 1 & 64.3 & 94.2 & 74.0 & 1.5 & 1.3 & 76.2 & 1.4 \\
\hline Spikes $/ 0.25 \mathrm{~m}^{2}$ & 1 & $153 \pm 6.8$ & $205 \pm 8.9$ & $174 \pm 5.5$ & $146 \pm 4.3$ & $153 \pm 4.3$ & $176 \pm 4.3$ & $149 \pm 3.6$ \\
\hline Spike length, $\mathrm{cm}$ & 2 & $8.6 \pm 0.2$ & $8.2 \pm 0.1$ & $6.8 \pm 0.2$ & $8.0 \pm 0.1$ & $8.4 \pm 0.2$ & $7.5 \pm 0.2$ & $8.1 \pm 0.1$ \\
\hline Spikelets/spike & 2 & $17.1 \pm 0.4$ & $14.5 \pm 0.3$ & $14.9 \pm 0.1$ & $17.1 \pm 0.2$ & $18.0 \pm 0.5$ & $15.3 \pm 0.2$ & $17.5 \pm 0.2$ \\
\hline Sterile spikelets, $\%$ & 2 & 14.3 & 23.4 & 24.0 & 19.4 & 15.7 & 21.7 & 17.3 \\
\hline Grains/spike & 2 & $26.2 \pm 1.4$ & $15.7 \pm 0.6$ & $15.0 \pm 0.4$ & $24.1 \pm 0.9$ & $28.6 \pm 0.8$ & $17.8 \pm 0.7$ & $26.2 \pm 0.6$ \\
\hline $\begin{array}{l}1000 \text { kernel weight, } \\
\text { g }\end{array}$ & 2 & $38.7 \pm 1.0$ & $42.8 \pm 0.7$ & $36.8 \pm 0.5$ & $32.8 \pm 0.5$ & $32.7 \pm 0.7$ & $38.6 \pm 0.5$ & $32.7 \pm 0.4$ \\
\hline Grain yield, kg/ha & 3 & $3368 \pm 90$ & $3033 \pm 65$ & $2849 \pm 57$ & $3218 \pm 68$ & $3626 \pm 69$ & $3014 \pm 66$ & $3408 \pm 53$ \\
\hline
\end{tabular}

WLR were characterized by early vigor in spring and fast and abundant growth prior to heading. The green area calculated using RGB digital photos and BreedPix software demonstrated 5.5\% higher values in WLR compared to that of MG from early March, when plants started to recover from winter, till post-anthesis in late May (Figure 3). As maturity and senescence advanced, the average green area between these two groups converged. Early vigor and large early biomass are important adaptation traits to close the soil cover, conserving moisture and suppressing the weeds. 


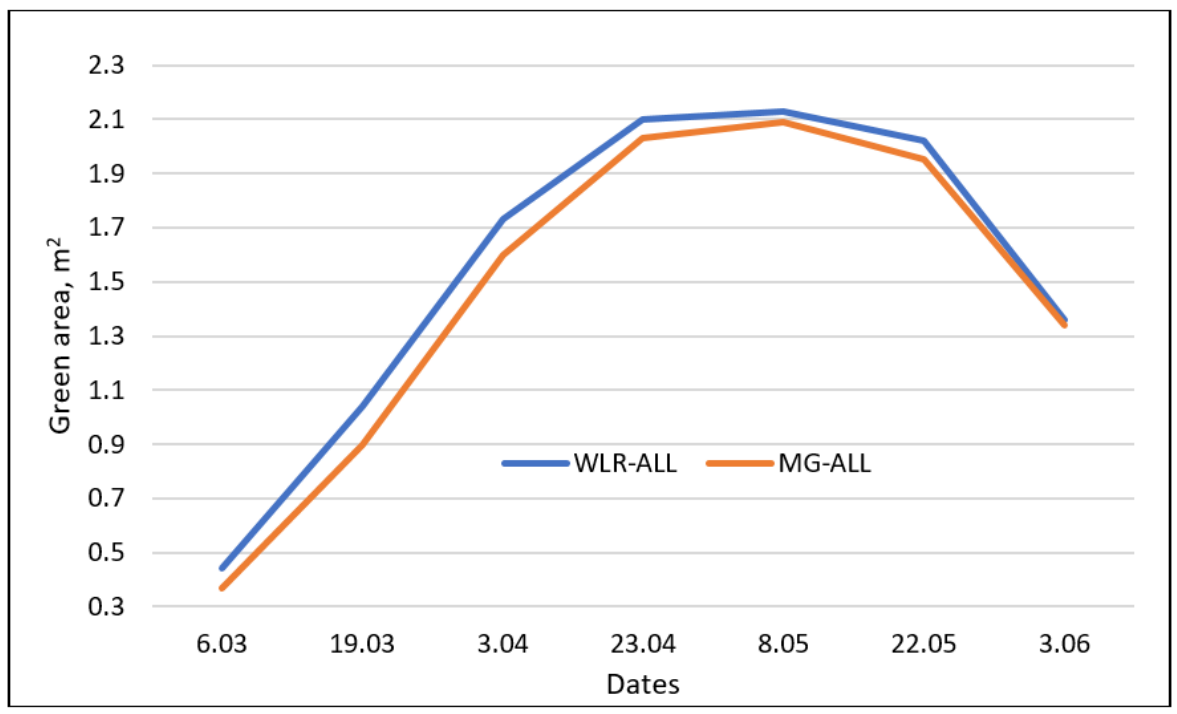

Figure 3. The dynamics of green area $\left(\mathrm{m}^{2}\right)$ changes for wheat landraces and modern germplasm at seven dates in 2019, Konya, Turkey.

There was substantial difference in resistance to stripe and leaf rust (Table 1 and Table S5). WLR were uniformly highly susceptible to leaf rust with average severity exceeding $55 \%$. However, there was a degree of resistance to strip rust (average severity $28.7 \%$ ) probably due to disease pressure and wheat landraces evolution through better adaptation of resistant genotypes. Leaf rust is much less spread in the region and does not affect the crop to the extent that stripe rust does.

\subsection{Grain Yield and Its Components}

Grain yield mean values for the three sites for two years are presented in Table 1 and for individual locations in Figure 4 and Table S5. Overall, the MG outyielded the WLR by $10 \%$ with average yields of 3.41 and $3.01 \mathrm{t} / \mathrm{ha}$, respectively. However, Afghan landraces were as high yielding as was MG in Afghanistan in 2019. There was no significant difference between WLR and MG in Iran in 2019. Afghan and Iranian landraces had significantly higher yields than did both MG groups under severe drought in Turkey in 2018. Abundant moisture in Turkey in 2019 clearly favored the MG. Among three WLR groups, the Afghan material was the highest yielding followed by those from Iran and Turkey.

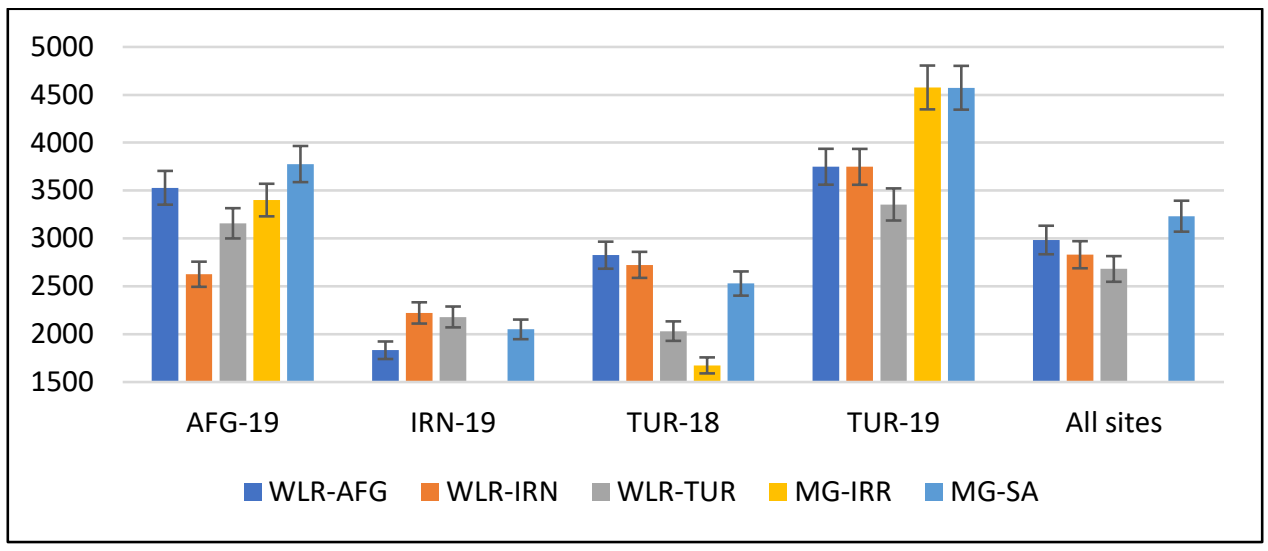

Figure 4. Grain yield of wheat landraces and modern germplasm at four testing sites.

WLR on average had $17.4 \%$ higher numbers of spikes per unit area. The spike size was similar in Afghan and Iranian WLR and MG, but it was much shorter in Turkish material due to the presence of club wheat. For the number of spikelets and grains per spike, Iranian 
and Turkish WLR were inferior to that of MG. Spikelets sterility was also higher in WLR. Thousand kernel weight was consistently higher in WLR across three sites and years with differences varying from $8.9 \%$ in Iran in 2019 (35.2 vs. 32.3 g) to $23.9 \%$ in Turkey in 2019 (44.0 vs. $35.5 \mathrm{~g})$.

\subsection{Relationship between Grain Yield and Agronomic Traits}

The relationship between grain yield, its components, and other traits was evaluated using PCR biplot analysis of trial results from Turkey in two contrasting seasons: droughtaffected 2018 and favorable 2019 (Figure 5). The biplots for all WLR demonstrated a diverse structure of the relationship among traits. In both years, grain yield was negatively related to the number of days to heading and spike sterility and positively to plant height. In 2018, 1000 kernel weight (TKW) was more closely associated with yield, whereas in 2019 the number of grains per spike had a higher contribution to grain yield. The same biplots for MG were much more "coordinated" and one-dimensional. Independently of the year, the grain yield was negatively correlated with spike sterility and positively with the number of grains per spike. TKW association with yield was higher in 2018. The main difference between two groups of material was the negative effect of earliness (number of days to heading) on grain yield in WLR, whereas this trait was less important for productivity contribution in MG. This is likely due to the lateness and relatively low yield of Turkish WLR. The structure of the relationship between agronomic and adaptation traits is important for designing the crossing and selection methodology to maximize grain yield.
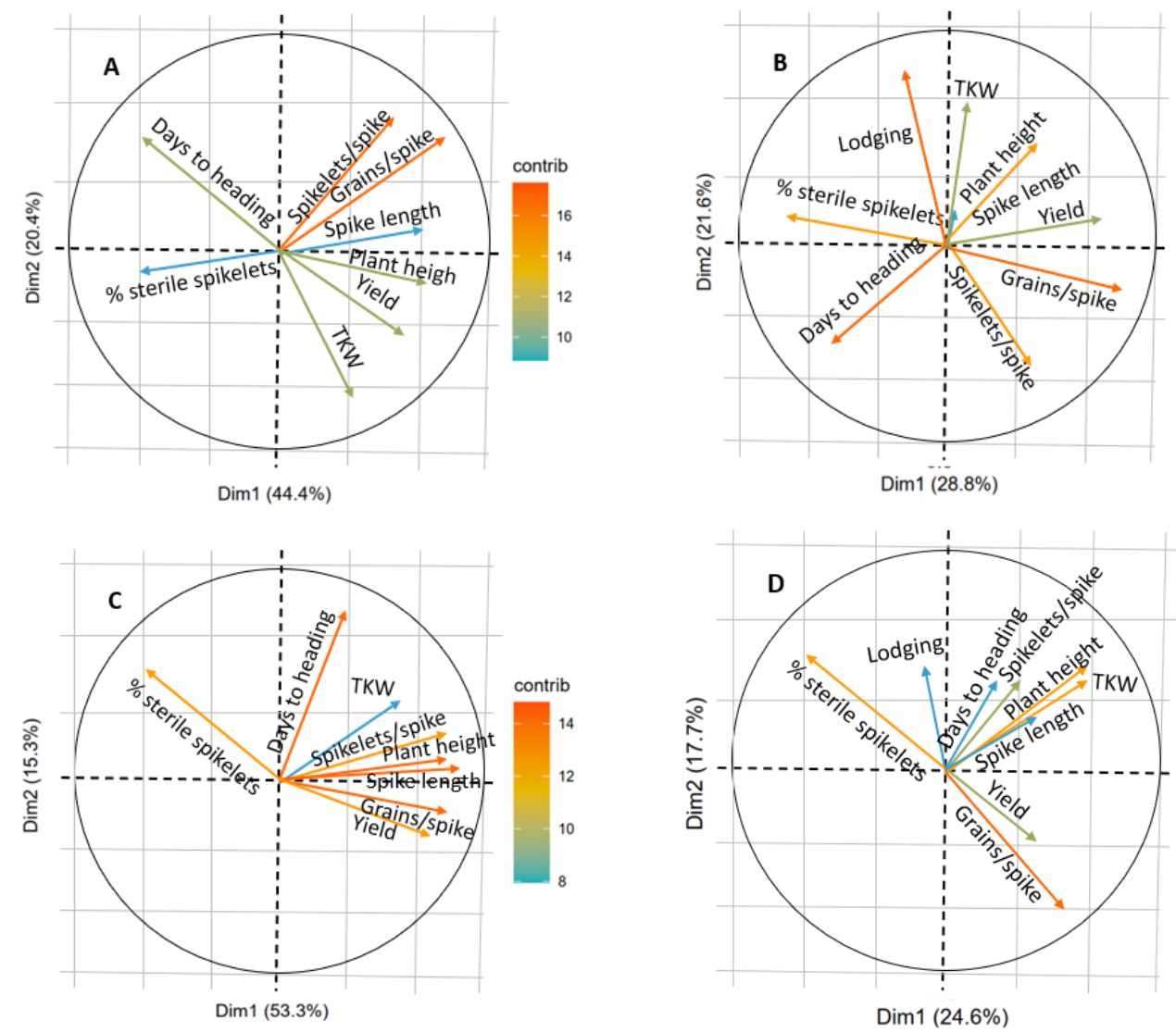

Figure 5. Biplots for principal component analysis of grain yield, its components, and agronomic traits for WLR tested in Konya, Turkey in 2018 (A), 2019 (B) and MG in 2018 (C) and 2019 (D). 


\subsection{Molecular Markers Frequencies and Traits Associations}

Despite the large number of molecular markers used to characterize the material, only a few were eventually selected due to unbalanced frequency and lack of phenotypic data to analyze marker-trait associations.

None of the WLR possessed 1B.1R translocation, whereas five genotypes representing MG had this marker. Allele Ppd-D1b controlling sensitivity to daylength was found in $75 \%$ of WLR and 35\% of MG, representing a major selection frequency shift towards insensitivity. However, comparing the number of days to heading of MG with insensitive and sensitive alleles did not identify any significant differences. Markers for $V r n-A 1$ alleles did not show sufficient variation, with winter type alleles being most frequent. There was variation for the presence of different alleles of $V r n-B 1$ and $V r n-D 1$ genes but it did not relate to actual growth habits observed in the material. The frequency of the drought tolerant allele of the Dreb1 gene was 15\% in WLR and 53\% in MG, but its presence was not manifested in increased grain yield. The Glu-D1d allele controlling strong gluten subunits $5+10$ was present in only $6 \%$ of WLR, whereas its frequency was $70 \%$ in MG, again representing a major shift. However, this study did not analyze grain quality parameters.

The genes controlling leaf rust had an interesting distribution and effects on pathogen severity. Gene Lr34 was totally absent in wheat landraces but its frequency in breeding material was $44.4 \%$. Testing at a leaf rust hotspot in Adapazari in Turkey demonstrated substantial reduction in leaf rust severity due to presence of this gene: $20.9 \%$ vs. $26.1 \%$ in 2018 and $29.5 \%$ vs. $38.5 \%$ in 2019 . Gene $L r 46$ was present in $40.5 \%$ of all landraces and $45.8 \%$ of modern germplasm. The leaf rust severity reduction due to the presence of the gene was $46-40 \%$ in both years of testing. The gene Sus $2-2 B$ contributes to TKW. The frequency of the allele controlling for higher grain size was $64.3 \%$ in WLR and only $2.7 \%$ in MG. The presence of this gene had significant positive effect on 1000 kernel weight across three sites resulting in an overall increase of $3.8 \%: 38.1 \mathrm{vs.} 36.7 \mathrm{~g}$ (Figure S1). This important gene has essentially been lost through modern breeding.

\subsection{Agronomic Performance of Superior Landraces}

Grain yield, adaptation, and agronomic traits for the checks and the five highest yielding genotypes in each group are presented in Table 2. The grain yield for longterm checks Bezostaya and Gerek was 3.5-3.7 t/ha across four trials. For modern checks, Nacibey and Karahan, the yield was slightly above $3.8 \mathrm{t} / \mathrm{ha}$. The highest yielding Afghan WLR was entry 9-Roshan safed khosha at $4.0 \mathrm{t} / \mathrm{ha}$, Iranian WLR 37-Qzil khosheh at $3.5 \mathrm{t} / \mathrm{ha}$ and Turkish WLR 50-Şergun at $3.8 \mathrm{t} / \mathrm{ha}$. The highest yielding breeding line was 128-Nd643/2*Waxwing/4/Tam200/Kauz/3/Agri/Bjy//Vee from the semiarid group (4.1 $\mathrm{t} / \mathrm{ha}$ ) followed by 12-Grk79//Inqalab 91*2/Tukuru from the irrigated group (4.0 t/ha). The highest yielding WLR were only marginally outyielded by the best modern cultivars and breeding lines (but the difference was not statistically significant).

Eight WLR were resistant to stripe rust: 9-Roshan safed khosha, 6-Nesh shotor (Afghanistan), 23-Sardari biotype, 30-Sardari biotype (Iran), 50-Şergun, 60-Kirmizi buğday, 54-Hinta, 45-Akbugday (Turkey). The average TKW of local checks ranged from of 32 to $35 \mathrm{~g}$ and for only one cultivar, Konya-2002, did this parameter slightly exceed $40 \mathrm{~g}$. Among the highest yielding WLR presented in Table 2, eight had TKW values higher than $41.5 \mathrm{~g}$. The study identified superior wheat landraces combining high yield potential with drought tolerance, stripe rust resistance, and large grain. 
Table 2. Agronomic performance of highest yielding wheat landraces, modern cultivars, and breeding lines.

\begin{tabular}{|c|c|c|c|c|c|c|c|c|c|}
\hline \multirow[b]{2}{*}{ Entry } & \multirow[b]{2}{*}{ Local Name } & $\begin{array}{c}\text { Growth } \\
\text { Habit }\end{array}$ & $\begin{array}{l}\text { Days to } \\
\text { Heading }\end{array}$ & $\begin{array}{l}\text { Plant Height, } \\
\text { cm }\end{array}$ & $\begin{array}{l}\text { Stripe } \\
\text { Rust, \% }\end{array}$ & $\begin{array}{l}\text { Leaf Rust, } \\
\%\end{array}$ & Grains/Spike & TKW, g & $\begin{array}{l}\text { Yield, } \\
\text { kg/ha }\end{array}$ \\
\hline & & $\begin{array}{c}\text { TUR } \\
19\end{array}$ & $\begin{array}{r}\text { TUR } \\
18-19\end{array}$ & TUR 18-19 & TUR 18 & TUR 19 & $\begin{array}{r}\text { TUR } \\
18-19\end{array}$ & $\begin{array}{c}\text { TUR } \\
18-19\end{array}$ & $\begin{array}{c}\text { AFG19 } \\
\text { TUR } \\
18-19\end{array}$ \\
\hline \multicolumn{10}{|c|}{ Local Checks } \\
\hline 85 & Bezostaya (long term IRR LC) & $\mathrm{W}$ & 131 & 83 & 40 & 60 & 26.1 & 35.1 & 3438 \\
\hline 124 & Gerek (long term SA LC) & $\mathrm{W}$ & 131 & 82 & 40 & 40 & 19.5 & 31.7 & 3897 \\
\hline 88 & Nacibey (IRR LC) & $\mathrm{W}$ & 131 & 82 & 0 & 40 & 33.4 & 35.3 & 3203 \\
\hline 125 & Karahan (SA LC) & $\mathrm{F}$ & 131 & 84 & 0 & 40 & 22.8 & 31.9 & 4020 \\
\hline \multicolumn{10}{|c|}{ Afghanistan WLR } \\
\hline 9 & Roshan safed khosha & $\mathrm{S}$ & 133 & 91 & 5 & 50 & 29.0 & 34.6 & 4183 \\
\hline 5 & Shanaze & $\mathrm{S}$ & 127 & 98 & 40 & 60 & 21.4 & 38.0 & 4100 \\
\hline 7 & Safedak kalak bedon e dasa & $S$ & 129 & 98 & 70 & 40 & 28.2 & 41.5 & 3803 \\
\hline 1 & Kalak robat sangi & $\mathrm{S}$ & 129 & 99 & 60 & 60 & 26.1 & 43.2 & 3694 \\
\hline 6 & Nesh shotor & $\mathrm{F}$ & 132 & 101 & 5 & 20 & 35.3 & 50.3 & 3656 \\
\hline \multicolumn{10}{|c|}{ Iran WLR } \\
\hline 24 & Khosheh ablaq & $\mathrm{W}$ & 129 & 88 & 40 & 50 & 21.1 & 41.4 & 3675 \\
\hline 37 & Qzil khosheh & $\mathrm{F}$ & 132 & 90 & 30 & 40 & 22.5 & 36.7 & 3454 \\
\hline 23 & Sardari biotype & $\mathrm{W}$ & 130 & 83 & 0 & 60 & 12.7 & 42.3 & 3359 \\
\hline 30 & Sardari biotype & W & 127 & 81 & 10 & 50 & 15.5 & 43.5 & 3124 \\
\hline 21 & Sardari biotype & $\mathrm{W}$ & 128 & 80 & 50 & 70 & 15.3 & 47.9 & 3067 \\
\hline \multicolumn{10}{|c|}{ Turkey WLR } \\
\hline 60 & Kirmizi buğday & W & 130 & 81 & 0 & 50 & 14.8 & 38.1 & 3908 \\
\hline 50 & Şergun & $\mathrm{W}$ & 131 & 85 & 0 & 40 & 17.3 & 42.4 & 3890 \\
\hline 54 & Hinta & $\mathrm{F}$ & 130 & 81 & 0 & 40 & 16.2 & 38.3 & 3514 \\
\hline 62 & Akbugday & $\mathrm{F}$ & 135 & 79 & 80 & 40 & 17.6 & 37.1 & 3355 \\
\hline 45 & Akbugday & $\mathrm{F}$ & 132 & 79 & 0 & 50 & 15.6 & 38.9 & 3196 \\
\hline \multicolumn{10}{|c|}{ MG-IRR } \\
\hline 112 & Grk79//Inqalab 91*2/Tukuru & $\mathrm{S}$ & 129 & 72 & 0 & 30 & 30.5 & 36.2 & 4171 \\
\hline 107 & $\begin{array}{l}\text { Tam200*2/Mo88//Kamb1*2/ } \\
\text { Kukuna/3/Sw89- } \\
\text { 3218/Vorona }\end{array}$ & W & 131 & 63 & 40 & 60 & 22.4 & 32.3 & 3757 \\
\hline 93 & $\begin{array}{l}\text { Agri/Nac//Kauz/3/1d13.1/Mlt/4 } \\
\text { Atay/Galvez87//Shark-1 }\end{array}$ & $4 / \mathrm{W}$ & 129 & 59 & 10 & 50 & 24.1 & 29.7 & 3636 \\
\hline 114 & Mv Sed & W & 127 & 61 & 5 & 50 & 23.2 & 31.8 & 3606 \\
\hline 95 & Mt0419/Destin//Bonito-36 & $\mathrm{W}$ & 131 & 70 & 0 & 40 & 26.1 & 31.5 & 3584 \\
\hline \multicolumn{10}{|c|}{ MG-SA } \\
\hline 128 & $\begin{array}{l}\text { Nd643/2*Waxwing/4/Tam200/ } \\
\text { Kauz/3/Agri/Bjy//Vee }\end{array}$ & F & 131 & 79 & 0 & 0 & 28.2 & 33.2 & 4335 \\
\hline 142 & Spartanka//Pbw343*2/Kukuna & W & 133 & 78 & 0 & 20 & 31.5 & 36.6 & 4138 \\
\hline 139 & Sultan95/Atilla//Zargana-6 & $\mathrm{W}$ & 136 & 98 & 0 & 70 & 29.8 & 37.2 & 4023 \\
\hline 138 & $\begin{array}{l}\text { Ks00f5-14- } \\
\text { 7/Eureka/ / Zargana-4 }\end{array}$ & $\mathrm{F}$ & 135 & 95 & 0 & 60 & 29.1 & 39.6 & 4007 \\
\hline \multirow[t]{2}{*}{133} & $\begin{array}{l}\text { Vorona//Milan/Sha7/3/Mv17/4/ } \\
\text { Atay/Galvez87//Shark-1 }\end{array}$ & $\mathrm{W}$ & 131 & 74 & 0 & 40 & 30.0 & 34.7 & 3919 \\
\hline & LSD 0.05 & - & 6 & 5.8 & - & - & 5.2 & 6.3 & 514 \\
\hline
\end{tabular}

\section{Discussion}

Wheat landraces have been attracting the attention of researchers for their diversity, expressed in their morphology, patterns of adaptation, and grain quality. However, diversity as such is frequently considered a positive character or a trait which is valued and requires introduction and maintenance in wheat cultivars. This study clearly demonstrated considerably higher morphological diversity of the landraces relative to modern cultivars, although genomic diversity based on SNP was slightly higher in modern material. As 
such, phenotypic and genetic diversity may have limited value unless they contribute to superior agronomic performance, tolerance to stresses, or product quality. The farmers in Central and West Asia who continue growing landraces are not interested in genetic diversity as a concept nor its on-farm conservation. The landraces have survived till now because they provide the utility to farmers through grain and straw of reasonable stable yield and excellent quality. A socioeconomic survey in Turkey showed that the majority of the farmers were satisfied with their landraces [7]. The current study raises two important questions: how can the diversity of the landraces be kept in farmers' fields, and how can landraces be used in wheat breeding?

This study demonstrated that the best WLR were as high yielding as were the MG across sites and years due to drought tolerance and relatively good response to favorable conditions. They were also characterized by early vigor and large biomass prior to heading. The landrace lodged in environments with grain yields approaching $4 \mathrm{t} / \mathrm{ha}$. Unexpectedly, spike sterility was higher in WLR despite large source volume (biomass) and relatively small sink (smaller spikes). MG had higher SNP diversity compared to that of WLR, confirming results from other studies [17].

The presence of the gene Sus2-2B contributed to high kernel weight, but this gene was almost entirely lost in modern material. However, the important gene Lr34, contributing to durable leaf rust resistance, was not present in the WLR and the frequency of the gene Glu-D1d, controlling strong gluten subunits $5+10$, occurred at a relatively low frequency. Cavanagh et al. [18] compared SNP diversity in a worldwide sample of 2994 accessions of hexaploid wheat including landraces and modern cultivars. The impact of crop improvement on genomic and geographic patterns of genetic diversity was documented including selective sweeps for genes involved in adaptation. In addition, a number of genetic studies have identified genes contributing to agronomic performance of wheat landraces from Turkey [19], Iran [20], and Afghanistan [21], including a few from the current study. The GWAS analysis is underway for the WLR and MG from this study, and preliminary results indicate confirmation of the known genes and discovery of the new ones.

From a practical breeding perspective, the key question that remains is how to best use the wealth of phenotypic and genomic information to improve modern wheat using landraces. IWWIP is based in Turkey and has access to superior WLR from large local and regional collections. Annually, up to 50-70 simple crosses have been made and exposed to selection pressure under moisture limited conditions. However, in favorable years, selected progenies would lodge and suffer from stripe and leaf rust, resulting in a low frequency of lines meeting all the desired selection criteria. The populations derived from top- or backcrosses WLR $\times$ MG $\times$ MG would be shorter and more resistant to disease but would largely lose drought tolerance and special quality characteristics. It appears that breeding modern material using landraces resembles pre-breeding with step-by-step crosses, selection and crosses, and selection again [22]. Utilization of molecular markers including the genes identified in this study greatly enhances the efficiency. In fact, previous successes in breeding commercial cultivars using WLR originate from the use of specific traits through robust high throughput phenotyping and are frequently guided by molecular markers. The examples include resistance to Fusarium head blight [23] and Zn content [24].

There is also an alternative breeding strategy to improve the landraces by combination of complementary traits or incorporation of traits/genes of interest such as the ones controlling plant height or disease resistance. This approach was successfully used at the University of California, Davis to develop and register "heirloom-like varieties" of dry beans. Journal of Plant Registrations, 2021, Volume 1 included five papers describing heirloom-like beans cultivars. One example is UC Rio Zape dry bean (Phaseolus vulgaris) cultivar (PI 693471) developed by recurrent backcrossing between the landrace Rio Zape (recurrent parent) and Matterhorn (donor parent) [25]. UC Rio Zape traces about 98\% of its ancestry to Rio Zape but demonstrates resistance to bean common mosaic virus due to introgression of the I gene. Producers' and consumers' interest in heirlooms and organic products contribute to interest in breeding improved landraces. 
The landraces improvement breeding strategy can also benefit the farmers in West Asia who still grow landraces. The pressure from modern technology and cultivars contributes to gradual loss of on-farm genetic diversity in wheat [7], especially because younger generations of farmers are less interested in traditional ways of farming. New improved and diverse wheat landraces will keep their competitive advantage if they maintain traits such as yield stability and grain and straw quality combined with improved disease and lodging resistance.

IWWIP within the Benefit-Sharing Fund project attempted two distinct approaches. Firstly, selections were made among the progenies originating from a particular landrace, being either mixed or phenotypically uniform. Modern phenotyping and genomic tools were applied, and, frequently, fast genetic progress was made for yield and other traits including disease resistance. Selected agronomically superior lines were multiplied and either mixed again to maintain the original diversity or the pure lines were provided back to the farming communities from where they had originated. In 2018-2019, more than 500 farmers in Afghanistan, Iran, and Turkey were supplied with the seeds of improved landraces. This approach also provided the opportunity for diversification of the landraces by exchanging the material between different regions, and even countries. The second approach was a targeted crossing and selection program between the landraces themselves to compliment essential traits. Segregating populations originating from these crosses were handled primarily on the station under moisture-limited conditions resembling the target areas. However, some populations were also provided to interested farmers to initiate a new cycle of participatory breeding and selection. The impact of these two approaches is yet to be evaluated.

There is general agreement that changing diets and increasing consumer preference for local, diverse, and healthy foods favor wheat landraces and wheat landraces-like cultivars [9]. The diversity of wheat landraces is available both in the gene banks and in farmer fields in Central and West Asia, and other regions. Recently, the evolving strategy of improving wheat landraces through selection or breeding heirloom-like cultivars has benefited not only the consumers in societies aspiring for healthy food but also the farmers who preserve them and continue their cultivation. Consequently, there is a likelihood that wheat landraces and derived cultivars will continue to be grown by smallholders in the region and possibly expanded areas in the future.

Supplementary Materials: The following are available online at https: / www.mdpi.com/article/ $10.3390 /$ crops1020007/s1, Table S1. List of materials used in the study, Table S2. Names and characteristics of the main morphotypes of Triticum aestivum ssp. aestivum and T. turgidum ssp. durum, Table S3. The list of KASP markers used in the study, Table S4. Distribution of WLR and MG according to botanical varieties, Table S5. Agronomic parameters of wheat landraces and modern germplasm tested in Afghanistan, Iran, and Turkey, 2018-2019, Figure S1. 1000 kernel weight of wheat landraces possessing different Sus2-2B alleles.

Author Contributions: Conceptualization, A.M., F.Ö., Mesut Keser and R.S.; methodology, S.D. and R.S.; validation, A.M., F.Ö., Mesut Keser and R.S.; formal analysis, R.S.; investigation, B.A., A.A.D., S.D., S.G., E.K., Murat Küçükçongar, A.N., A.R., M.R., D.S. and R.S.; resources, H.M.; data curation, D.S. and E.K.; writing-original draft preparation, A.M. and R.S.; writing-review and editing, A.A.D., S.G. and H.M.; visualization, A.N.; supervision, F.Ö., Mesut Keser and S.G.; project administration, A.M.; funding acquisition, A.M. All authors have read and agreed to the published version of the manuscript.

Funding: This research was conducted with the financial assistance of the European Union within the framework of the Benefit-Sharing Fund project "W2B-PR-41-TURKEY" of the FAO's International Treaty on Plant Genetic Resources for Food and Agriculture. The views expressed in this document are those of the author(s) and do not necessarily reflect the views or policies of the European Union or FAO.

Institutional Review Board Statement: Not applicable.

Informed Consent Statement: Not applicable. 
Data Availability Statement: The phenotypic data are available at CIMMYT Dataverse repositary https:/ / data.cimmyt.org/dataset.xhtml?persistentId=hdl:11529/10548355 (accessed on 15 May 2021).

Acknowledgments: The staff of the Maize Research Institute at Sakarya, Turkey is acknowledged for evaluation of leaf rust resistance. Ian Riley is sincerely thanked for scientific editing of the manuscript. C.O. Qualset is sincerely thanked for inspiration and design of the study and advice on manuscript preparation.

Conflicts of Interest: The authors declare no conflict of interest. The funders had no role in the design of the study; in the collection, analyses, or interpretation of data; in the writing of the manuscript, or in the decision to publish the results.

\section{References}

1. Morgounov, A.; Ozdemir, F.; Keser, M.; Akin, B.; Payne, T.; Braun, H.-J. International Winter Wheat Improvement Program: History, activities, impact and future. Front. Agric. Sci. Eng. 2019, 6, 240-250. [CrossRef]

2. Keser, M.; Gummadov, N.; Akin, B.; Belen, S.; Mert, Z.; Taner, S.; Topal, A.; Yazar, S.; Morgounov, A.; Sharma, R.C.; et al. Genetic gains in wheat in Turkey: Winter wheat for dryland conditions. Crop J. 2017, 5, 533-540. [CrossRef]

3. Nehe, A.; Akin, B.; Sanal, T.; Kaplan, A.; Ünsal, R.; Dinçer, N.; Demir, L.; Geren, H.; Sevim, S.; Orhan, Ş.; et al. Genotype x environment interaction and genetic gain for grain yield and grain quality traits in Turkish spring wheat released between 1964 and 2010. PLoS ONE 2019, 14, e0219432. [CrossRef] [PubMed]

4. Buerkert, A.; Oryakhail, M.; Filatenko, A.; Hammer, K. Cultivation and taxonomic classification of wheat landraces in the upper Panjsher valley of Afghanistan after 23 years of war. Gen. Res. Crop Evol. 2006, 53, 91-97. [CrossRef]

5. Abbasabad, Z.; Mohammadi, E.; Moghaddam, A.; Kamali, M. Analysis of genetic diversity, population structure and linkage disequilibrium in Iranian wheat landraces using SSR markers. Plant Gen. Res. Charact. Util. 2017, 15, 327-334. [CrossRef]

6. Husenov, B.; Muminjanov, H.; Dreisigacker, S.; Otambekova, M.; Akin, B.; Subasi, K.; Rasheed, A.; Shepelev, S.; Morgounov, A. Genetic diversity and agronomic performance of wheat landraces currently grown in Tajikistan. Crop. Sci. 2021. [CrossRef]

7. Morgounov, A.; Keser, M.; Kan, M.; Küçükçongar, M.; Özdemir, F.; Gummadov, N.; Muminjanov, H.; Zuev, E.; Qualset, C.O. Wheat landraces currently grown in Turkey: Distribution, diversity, and use. Crop. Sci. 2016, 56, 3112-3124. [CrossRef]

8. Baboev, S.; Muminjanov, H.; Turakulov, K.; Buronov, A.; Mamatkulov, I.; Koc, E.; Ozturk, I.; Dreisigacker, S.; Shepelev, S.; Morgounov, A. Diversity and sustainability of wheat landraces grown in Uzbekistan. Agron. Sustain. Dev. 2021, 41, 1-13. [CrossRef]

9. Shewry, P.R. Do ancient types of wheat have health benefits compared with modern bread wheat? J. Cereal Sci. 2018, 79, 469-476. [CrossRef]

10. Dwivedi, S.; Goldman, I.; Ortiz, R. Pursuing the potential of heirloom cultivars to improve adaptation, nutritional, and culinary features of food crops. Agronomy 2019, 9, 441. [CrossRef]

11. Zuev, E.; Amri, A.; Brykova, A.; Pyukkenen, V.; Mitrofanova, O. Atlas of Bread Wheat (Triticum aestivum L.) Genetic Diversity Based on Spike and Kernel Characters; N.I. Vavilov Research Institute of Plant Industry (VIR): St. Petersburg, Russia, 2013 ; pp. 3-78.

12. Pask, A.; Pietragalla, J.; Mullan, D.; Reynolds, M. Physiological Breeding II: A Field Guide to Wheat Phenotyping; CIMMYT: Mexico City, Mexico, 2012; pp. 1-132.

13. Casadesus, J.; Villegas, D. Conventional digital cameras as a tool for assessing leaf area index and biomass for cereal breeding. $J$ Integr. Plant Biol. 2014, 56, 7-14. [CrossRef]

14. Botstein, D.; White, R.; Skolnick, M.; Davis, R. Construction of a genetic linkage map in man using restriction fragment length polymorphisms. Am. J. Hum. Genet. 1980, 32, 314-331. [PubMed]

15. Dreisigacker, S.; Sehgal, D.; Reyes Jaimez, A.E.; Luna Garrido, B.; Muñoz Zavala, S.; Núñez Ríos, C.; Mollins, J.; Mall, S. CIMMYT Wheat Molecular Genetics: Laboratory Protocols and Applications to Wheat Breeding; CIMMYT: Mexico City, Mexico, 2016; pp. 1-154.

16. Khalid, M.; Afzal, F.; Gul, A.; Amir, R.; Subhani, A.; Ahmed, Z.; Mahmood, Z.; Xia, X.; Rasheed, A.; He, Z. Molecular characterization of 87 functional genes in wheat diversity panel and their association with phenotypes under well-watered and water-limited conditions. Front. Plant Sci. 2019, 10, 717. [CrossRef]

17. Rufo, R.; Alvaro, F.; Royo, C.; Soriano, J.M. From landraces to improved cultivars: Assessment of genetic diversity and population structure of Mediterranean wheat using SNP markers. PLoS ONE 2019, 14, 0219867. [CrossRef]

18. Cavanagh, C.R.; Chao, S.; Wang, S.; Huang, B.E.; Stephen, S.; Kiani, S.; Forrest, K.; Saintenac, C.; Brown-Guedira, G.L.; Akhunova, A.; et al. Genome-wide comparative diversity uncovers multiple targets of selection for improvement in hexaploid wheat landraces and cultivars. Proc. Natl. Acad. Sci. USA 2013, 110, 8057-8062. [CrossRef]

19. Sehgal, D.; Dreisigacker, S.; Belen, S.; Küçüközdemir, Ü.; Mert, Z.; Özer, E.; Morgounov, A. Mining centuries old in situ conserved Turkish wheat landraces for grain yield and stripe rust resistance genes. Front. Gen. 2016, 7, 201. [CrossRef]

20. Rahimi, Y.; Bihamta, M.R.; Taleei, A.; Alipour, H.; Ingvarsson, P.K. Genome-wide association study of agronomic traits in bread wheat reveals novel putative alleles for future breeding programs. BMC Plant Biol. 2019, 19, 541. [CrossRef]

21. Manickavelu, A.; Joukhadar, R.; Jighly, A.; Lan, C.; Huerta-Espino, J.; Stanikzai, A.S.; Kilian, A.; Singh, R.P.; Ban, T. Genome wide association mapping of stripe rust resistance in Afghan wheat landraces. Plant Sci. 2016, 252, 222-229. [CrossRef] 
22. Shokat, S.; Sehgal, D.; Liu, F.; Singh, S. GWAS analysis of wheat pre-breeding germplasm for terminal drought stress using next generation sequencing technology. Preprints 2020, 2020020272. [CrossRef]

23. Buerstmayr, M.; Steiner, B.; Buerstmayr, H. Breeding for Fusarium head blight resistance in wheat-Progress and challenges. Plant Breed. 2020, 139, 429-454. [CrossRef]

24. Velu, G.; Singh, R.; Crespo-Herrera, L.; Juliana, P.; Dreisigacker, S.; Valluru, R.; Stangoulis, J.; Sohu, V.; Mavi, G.S.; Mishra, V.K.; et al. Genetic dissection of grain zinc concentration in spring wheat for mainstreaming biofortification in CIMMYT wheat breeding. Sci. Rep. 2018, 8, 13526. [CrossRef]

25. Parker, T.; Palkovic, A.; Brummer, C.; Gepts, P. Registration of 'UC Rio Zape' heirloom-like dry bean. J. Plant Reg. 2021, 15, 37-42. [CrossRef] 